\title{
ランダム・セントロイド最適化法を用いた真空調理法による 肉じゃがの最適減塩調理条件の検討
}

\author{
後藤昌弘 $*$ ·西村公雄 $* *$ 中井秀了*** \\ (*高知女子大学生活科学部, **同志社女子大学生活科学部, ***ブリティッシュ・コロンビア州立大学)
}

\section{Search of Optimum Reduced Salt Cooking Condition on Nikujyaga by Vacuum Cooking Using Random Centroid Optimization.}

\author{
Masahiro Goto*, Kimio Nishimura**, Shuryo Nakai*** \\ *Kochi Women's University, 5-15, Eikokuji-cho, Kochi, 780-8515 \\ **Doshisha Women's College of Liberal Arts, Genbu-cho, Imadegawa, Kamigyo-ku, Kyoto 602-0893 \\ ${ }^{* * *}$ University of British Columbia, Vancouver, BC, V6T 1Z4, Canada \\ * $7780-8515$ 高知市永国寺町 $5-15$ \\ **T602-0893 京都市上京区今出川通寺町西入玄武町 602
}

\begin{abstract}
The optimum cooking conditions for low-salt Nikujyaga prepared by vacuum cooking were determined by using the random centroid optimization (ROC) method. The quantities of the seasoning for vacuum cooking were selected with reference to eight popular cooking books and decided the heating time were $40 \mathrm{~min}$ at $100^{\circ} \mathrm{C}$ by ranking test. The low-salt Nikujyaga made by vacuum cooking was preferred by scoring method, so the optimum condition for vacuum cooking were investigated by RCO search regarding the two factors of soy sauce weight and sugar weight in the constant concentration of bonito broth seasoning.

The optimum soy sauce weight and sugar weight in the stock were $16.6 \mathrm{~g}$ and $4.2 \mathrm{~g}$, respectively, from the overall preference score. The amount of salt was reduced by $33 \%$ compared with ordinal cooking under these conditions. In the same way, it was investigated regarding three factors of soy sauce weight, sugar weight and bonito broth seasoning powder weight. The optimum soy sauce weight, sugar weight and broth powder weight were $13.4 \mathrm{~g}, 5.5 \mathrm{~g}$ and $1.7 \mathrm{~g}$, respectively. The amount of salt was reduced by $38 \%$ compared with ordinal cooking under these cooking conditions.
\end{abstract}

\section{1. 緒言}

従来, 経験や勘で求められてきた相互関係のある因子 の最適条件を簡便に得る方法の一つに Random Centroid Optimization Method ${ }^{1 \sim 5}$ ) (ランダム・セントロイ ド最適化法, 以下 $\mathrm{RCO}$ 法と略す）がある. 一方, 真空 調理法6 8) は従来の調理法とは異なった食感の料理を提
供することができると注目されている調理法の一つであ る、これまでに筆者 ${ }^{9,10)}$ は真空調理法には調味液をし みこませる料理が適することを報告している.なかでも， 肉じゃがは, 調味液の塩分濃度を設定して調理すれば, 真空調理法の特性が利用でき, 食味の良い減塩効果が期 待できる. そこで, 本研究では真空調理法による肉じゃ がの最適減塩調理条件を RCO 法を用いてできるだけ少 
ない回数で決定することを試みた。

\section{2. 実験方法}

1) 材 料: ジャガイモは, 北海道産 ‘男爵薯’（1 個の平均重量 $120 \mathrm{~g}$ ，デンプン含量約 $19 \%)$ ， ニンジンは ‘向陽’，タマネギは‘もみじ’を用いた。これらは，高 知市内小売業者から購入した. 牛肉は, 高知市内精肉店 で購入した牛肉（薄切り，赤身）を用いた。調味料の上 白糖 (三井製糖製)，本醸造濃口奨油 (キッコーマン製), カツオ風味調味料 (味の素製) は, 市販品を購入した。 真空包装は, 市販の真空包装用プラスチック袋（HN 105 ，旭化成製， $28.4 \mathrm{~cm} \times 18.0 \mathrm{~cm} ）$ を用いた.

2 ) 調理方法: ジャガイモは, 剥皮後一口大（約 3 $\mathrm{cm}$ 角）に切り，水に浸漬した後，水気を切った。 ニン シン, タマネギは剥皮後, 一口大 (それぞれ約 $3 \mathrm{~cm}$ 角), 牛肉も一口大 ( $5 \mathrm{~cm}$ 程度) に切った.

肉じゃがは, 真空包装用プラスチック袋に上述のよう に調製したジャガイモ $190 \mathrm{~g}$ ，ニンジン $90 \mathrm{~g}$ ，タマネギ $90 \mathrm{~g}$, 牛肉 $75 \mathrm{~g}$ と調味液 $160 \mathrm{~g}$ (水 $130.9 \mathrm{~g}$, 奨油 $19.5 \mathrm{~g}$, 砂 糖 $8.4 \mathrm{~g}$, 風味調味料 $1.2 \mathrm{~g}$ ) を入れて真空包装し, スチー ム・コンベクションオーブン（FMI 製 CF-43M）を用 いて $100{ }^{\circ} \mathrm{C} て ゙$ 加熱調製した。なお, 調味液中の調味料の 量は, 市販の料理書 8 冊 11 18) の条件の平均值と風味調 味料の使用法に記載された基本濃度を真空包装用袋に入 る最大量に換算して決定した。これを以後一般的調味液 という.

真空包装は，真空包装機（東静電気製 V-303G）を 用い, 真空度を $96 \%(-730 \mathrm{mmHg})$ 以上になるように 設定した.

まず，適当な加熱時間を求めるため，この調理条件で $20,30,40$ 分加熱し, 冷水中で急冷後, 冷蔵庫で一夜放 置したものを10分間スチーム・コンベクションオーブン $\left(100{ }^{\circ} \mathrm{C}\right)$ で再加熱し, 官能検査に供した. 供試時の品温

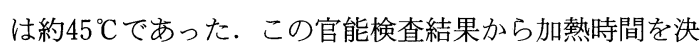
定した。

次に最適減塩調理条件を検討するため, 先に調製した ものと同重量の野菜及び肉を真空包装用袋に入れ, RCO プログラムで設定された重量の調味料と水を合わ せて $160 \mathrm{~g}$ を調味液として加え, 所定時間加熱調理後,

一夜冷蔵庫で放置した．以後これを真空調理品肉じゃが という.

また，先に示した一般的調味液と RCO 法で得られた 最適条件の調味液それぞれに切った全材料を加えて鍋に 入れ，火にかけ約 20 分間煮る普通調理を行った. 以後,
前者を普通調理品肉じゃが, 後者を減塩普通調理品肉じ やがという。

3) RCO 法: 減塩最適条件の検索は, 中井ら ${ }^{1,2}$ 㤎作 成したプログラムを用いて，まず，風味調味料重量は一 定 $(1.2 \mathrm{~g})$ にし, 酱油重量, 砂糖重量の 2 つを条件と して, パーソナルコンピュータによって調理条件数值を ランダムに設定させた。条件範囲は㖶油重量 $0 \sim 19.5 \mathrm{~g}$, 砂糖重量 0 ～ $8.4 \mathrm{~g}$ とした. 最初の条件設定 (ランダムサー チ）では，9個の条件が出されたので，これに従って調 理をし, 官能検査を実施, 総合評価の平均値を応答とし て入力した． 9 個の総合評価平均值の入力により， 2 個 の条件が追加された（セントロイドサーチ）.さらに, これらの条件で調理と官能検査を行い, その結果を入力 して前報 4 , 10)に準じてマッピング法1)により最適值を探 索した。なお, 各調理で得られた評価は, 平均値士標準 偏差で示した。

次に, 風味調味料重量 $(0 \sim 3.0 \mathrm{~g})$, 奨油重量（０～ $16.6 \mathrm{~g})$, 砂糖重量（0８.4g）の3つを変動条件として 同様に $\mathrm{RCO}$ 法で条件を求めた.

また, 最高点であった実験点の評点と各実験点で得ら れた評点間の有意差検定は $t$ 検定によった.

4 ）官能検查 : 加熱時間の検討は, 高知女子大学食物 栄養学科学生 28 人をパネルとして, 外観, 香り, 味, 口 当たり, 総合評価の 5 項目について順位法で行い, ケン ドールの一致性係数で有意差を検定した. なお，具材は 1 片ずつすべて提示したが評価はジャガイモについての み行わせた。

$\mathrm{RCO}$ 法による調理条件の検討では同学科女子学生 20 名をパネルとして, 外観, 香り, 味, 総合評価の 4 項目 について評点法で官能検査を行ったが， RCO 法への応 答としてはより実際の食味評価に近い総合評価のみを取 り扱った。なお, 評価は普通調理品肉じゃがを標準とし て, 1 点（非常に悪い）加 7 点（非常に良い）で採点 する 7 点法とした.

5) 肉じゃがの調味溶液及び具材中の塩分測定 : 普通 調理品肉じゃが, 減塩普通調理品肉じゃが及び真空調理 品肉じゃがについて, 調味溶液はそのまま, 具材は一定 量の蒸留水を加え, ワーニングブレンダーで磨砕したろ 液について沈殿滴定法19)で $\mathrm{Cl}$ 量を求め, 食塩量に換算 した.

\section{3. 結果及び考察}

\section{（1）最適加熱時間の検討}

加熱 40 分は外観, 味, 口当たり, 総合評価で最も好ま 
れた（Table 1). 一方，加熱20分は香りを除くすべての 項目で最も好まれなかった：これは，加熱時間が短いも のは，煮くずれしておらず，味のしみ込みも良くなかっ たのに対し，40分加熱は適度の煮くずれがあり，味のし み込みが良かったためと推察される.これらの結果から， 以後の実験では加熱時間を40分とした。 なお, 予備実験 として50分加熱も行ったが，煮くずれが大きいためここ では除外した。

Table 1 Results of the ranking test Nikujyaga samples prepared by vacuum cooking to determined the heating time.

\begin{tabular}{lllll}
\hline Heating time (min.) & 20 & 30 & 40 & Coefficient a) \\
\hline Appearance & 67 & 58 & 43 & $0.188^{* *}$ \\
Flavor & 64 & 54 & 50 & 0.066 \\
Taste & 62 & 67 & 39 & $0.284^{* *}$ \\
Texture & 64 & 66 & 38 & $0.311^{* *}$ \\
Overall evaluation & 63 & 69 & 36 & $0.394^{* *}$ \\
\hline
\end{tabular}

The vacuum cooking conditions were selected from the average values from eight cooking books. Heating temperature was $100^{\circ} \mathrm{C}$. Each value shows the total number of ranking. The number of panelists was 28 .

a) : Kendall's coefficient of concordance. The values marked with ${ }^{* *}$ is significantly difference at the $p<0.01$ levels.

(2) RCO 法による最適減塩調理条件の検討とその減塩 効果

まず，風味調味料重量を一定，罗油及び砂糖重量の 2 つを要因とした場合にRCO 法によって得られた各実験 点の醤油重量と砂糖重量及び官能検査の総合評価の評点 の平均値と標準偏差を Table 2 に示した. また, 最も評 価の良かった実験点 11 と他の実験点の間の有意差検定の 結果を表中に示した.

実験点No.1〜9はランダムサーチで設定されたもの で，その条件で調製した肉じゃがの総合評価の評点は 2.0〜4.0の範囲であった.これらの評点を入力して得ら れたのが実験点 No.10，11でこれをセントロイドサー チ5）と呼ぶ.ここで得られた条件で調製した肉じゃがの 評点 $3.5 ， 4.0$ を加えた合計11点の評点から榇油重量及び 砂糖重量の最適值をマッピング法により求めた. Fig. 1 -A は評点と奨油重量の関係を，Fig. 1-B は評点と砂糖 重量の関係を RCO プログラムによってプロットし，最 適值を探索したものである.矢印が最適点を示している. 両図とも実験点 $11 か ゙$ 最適値となり，奨油重量は $16.6 \mathrm{~g}$, 砂糖重量は $4.2 \mathrm{~g}$ であった.

この最適条件で調理した真空調理品肉じゃがと減塩普
Table 2 Vertices obtained by the RCO method and sensory evaluation scores.

\begin{tabular}{cccc}
\hline $\begin{array}{c}\text { Vertex. } \\
\text { No. }\end{array}$ & $\begin{array}{c}\text { Soy sauce } \\
\text { weight }(\mathrm{g})\end{array}$ & $\begin{array}{c}\text { Sugar } \\
\text { weight }(\mathrm{g})\end{array}$ & $\begin{array}{c}\text { Overall preference } \\
\text { score }(\mathrm{n}=20)\end{array}$ \\
\hline 1 & 5.9 & 8.2 & $2.8 \pm 1.15^{* *}$ \\
2 & 1.1 & 0.4 & $2.0 \pm 1.12^{* *}$ \\
3 & 15.5 & 4.6 & $3.4 \pm 0.81^{*}$ \\
4 & 6.2 & 2.7 & $2.3 \pm 0.83^{*}$ \\
5 & 14.6 & 2.3 & $3.0 \pm 0.89$ \\
6 & 19.3 & 1.3 & $3.7 \pm 0.81$ \\
7 & 5.2 & 4.3 & $2.6 \pm 0.50^{* *}$ \\
8 & 17.7 & 3.8 & $4.0 \pm 0.92$ \\
9 & 4.7 & 7.4 & $2.2 \pm 0.83^{* *}$ \\
$10^{* 1}$ & 18.5 & 2.5 & $3.5 \pm 0.89$ \\
$11^{* 1}$ & 16.6 & 4.2 & $4.0 \pm 1.12$ \\
\hline
\end{tabular}

Each value for the overall preference score is the mean \pm SD. Statistical significance shown by ${ }^{*}$ and ${ }^{* *}$ is at the $p<0.05$ and 0.01 levels, respectively, when compared with the overall evaluation scores at Vertex 11 by a $t$ - test. ${ }^{* 1}$ Centroid points from the first cycle.

通調理品肉じゃが並びに一般的調味料で調理した普通調 理品肉じゃがの 3 種について, 調味溶液及び具材の塩分 濃度を比較した（Fig. 2). 具材ではいずれも真空調理 品肉じゃがの塩分濃度が最も低くなっていた，全具材を あわせて比較すると普通調理品肉じゃがの塩分量を 100 とした場合, 減塩普通調理品肉じゃがが 82 , 真空調理品 肉じゃがが 67 とった。このことから，この最適条件で 真空調理を行うと普通調理品に比べ約 $33 \%$ の減塩効果が 得られることがわかった。

次にさらに減塩することを目的に㽜油重量は先の実験 の最適值であった $16.6 \mathrm{~g}$, 砂糖重量は一般的調理条件の $8.4 \mathrm{~g}$, 風味調味料は, 減塩してもうま味があればおい しく感じられることから一般的調理条件よりも多い $3.0 \mathrm{~g}$ を上限值とし, 奨油, 砂糖, 風味調味料重量の 3 つを変動条件とした。この場合に得られた各実験点の条 件と官能検査の総合評価の評点の平均値と標準偏差を Table 3 に示した. Table 2 と同様に No.1 9がランダ ムサーチ，10，11がセントロイドサーチである：この結 果を用いて同様にマッピング法で最適值を求めた. Fig. 3-A が評点と酱油重量, B が評点と砂糖重量, C が評点 と風味調味料重量の関係を RCO プログラムによってプ ロットし，最適值を探索したもので，矢印が最適值を示 している.いずれの図もNo.11が最適值となり，奨油 重量は $13.4 \mathrm{~g}$, 砂糖重量は $5.5 \mathrm{~g}$, 風味調味料重量は $1.7 \mathrm{~g}$ であった。

先と同様に，この最適条件で調理した真空調理品肉じ 

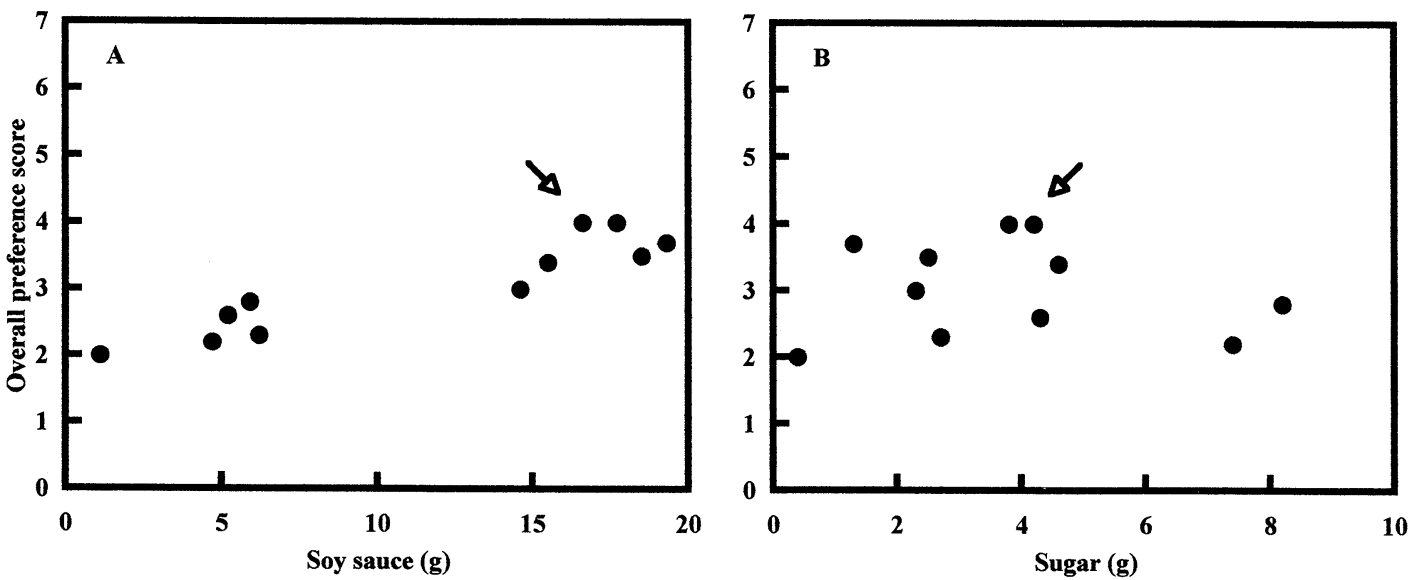

Fig. 1 Mapping results of the soy sauce weight and sugar weight in the seasoning solution generated by random centroid optimization.

A : Soy sauce weight, B : Sugar weight

The arrow indicates the optimum points.

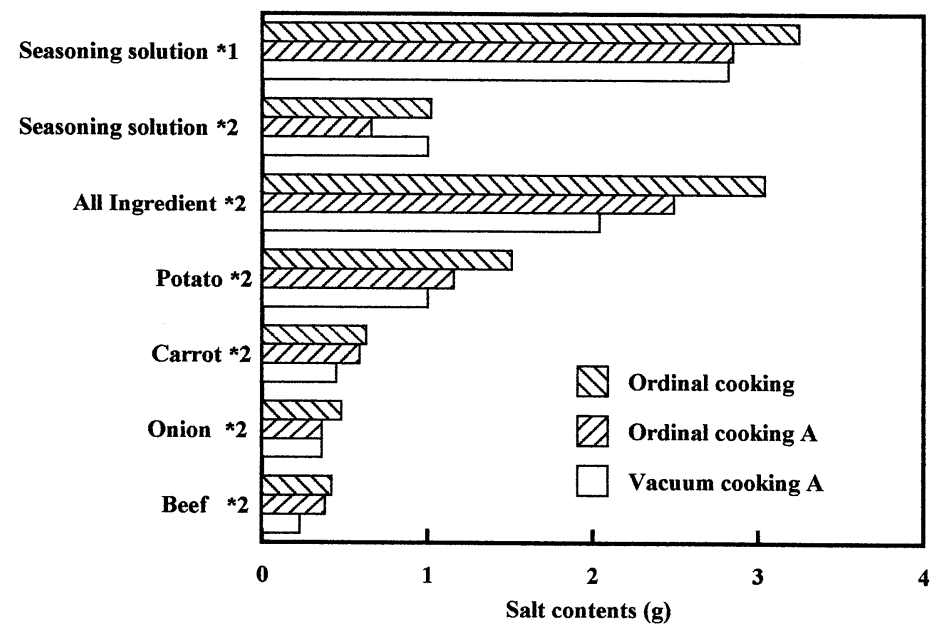

Fig. 2 Comparison of the salt content in the seasoning solution and ingredient cooked by ordinal cooking and low-salt vacuum cooking.

The conditions for ordinal cooking were the average values of eight popular cooking books. Ordinal cooking A was cooked by the same concentration of vacuum cooking A.

$*_{1}$ : before cooking $* 2$ : after cooking

やがとこれと同じ調味料濃度で調理した減塩普通調理品 肉じゃが並びに一般的調味料で調理した普通調理品肉じ やがの 3 種について, 調味溶液及び具材の塩分濃度を比 較した（Fig. 4). 具材ではいずれも真空調理品肉じゃ がの塩分濃度が低かった。 また，全具材の塩分量は普通 調理品肉じゃがを100とした場合，減塩普通調理品肉じ ゃがでは70, 真空調理品肉じゃがでは62であった。この ことから，この最適条件の真空調理品では $38 \%$ の減塩が
できることがわかった。

一般に 1 日の食塩量が普通食の $2 / 3$ 以下を減塩食と言 っているが，今回の実験では $2 つ の$ 実験とも $30 \%$ 以上の 減塩がなされており，減塩効果が期待できる。 また，一 般に減塩すると味が薄く感じられ，食味評価は低下する が, 真空調理品の場合, 普通調理を基準として行った官

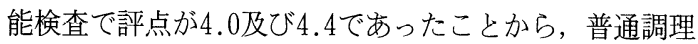
品とほとんど差がないと考えられ，減塩しても食味が低 
Table 3 Vertices obtained by the RCO method for three factors and sensory evaluation scores.

\begin{tabular}{ccccc}
\hline $\begin{array}{c}\text { Vertex. } \\
\text { No. }\end{array}$ & $\begin{array}{c}\text { Soy sauce } \\
\text { weight }(\mathrm{g})\end{array}$ & $\begin{array}{c}\text { Sugar } \\
\text { weight }(\mathrm{g})\end{array}$ & $\begin{array}{c}\text { Stock essence } \\
\text { weight }(\mathrm{g})\end{array}$ & $\begin{array}{c}\text { Overall preference } \\
\text { score }(\mathrm{n}=20)\end{array}$ \\
\hline 1 & 5.4 & 3.4 & 1.6 & $2.8 \pm 1.00^{*}$ \\
2 & 15.5 & 5.5 & 1.8 & $4.2 \pm 0.89$ \\
3 & 1.8 & 5.4 & 0.3 & $1.6 \pm 0.69^{* *}$ \\
4 & 2.0 & 8.0 & 2.6 & $2.7 \pm 0.59^{* *}$ \\
5 & 1.4 & 0.1 & 2.5 & $2.1 \pm 0.69^{* *}$ \\
6 & 3.0 & 0.6 & 2.1 & $1.8 \pm 0.55^{* *}$ \\
7 & 13.5 & 7.6 & 0.2 & $3.4 \pm 0.75^{* *}$ \\
8 & 11.3 & 3.3 & 3.0 & $4.0 \pm 1.00$ \\
9 & 13.6 & 5.7 & 1.3 & $3.5 \pm 1.28$ \\
10 & 13.5 & 4.8 & 2.0 & $4.1 \pm 1.25$ \\
$11^{* 1}$ & 13.4 & 5.5 & 1.7 & $4.4 \pm 0.99$ \\
$12^{* 1}$ & 14.2 & 6.3 & 1.1 & $4.3 \pm 1.25$ \\
\hline
\end{tabular}

Each value for the overall preference score is the mean \pm SD.

Statistical significance shown by ${ }^{*}$ and ${ }^{* *}$ is at the $p<0.05$ and 0.01 levels, respectively, when compared with the overall evaluation scores at Vertex 11 by a $t$ - test. ${ }^{* 1}$ Centroid points from the first cycle.
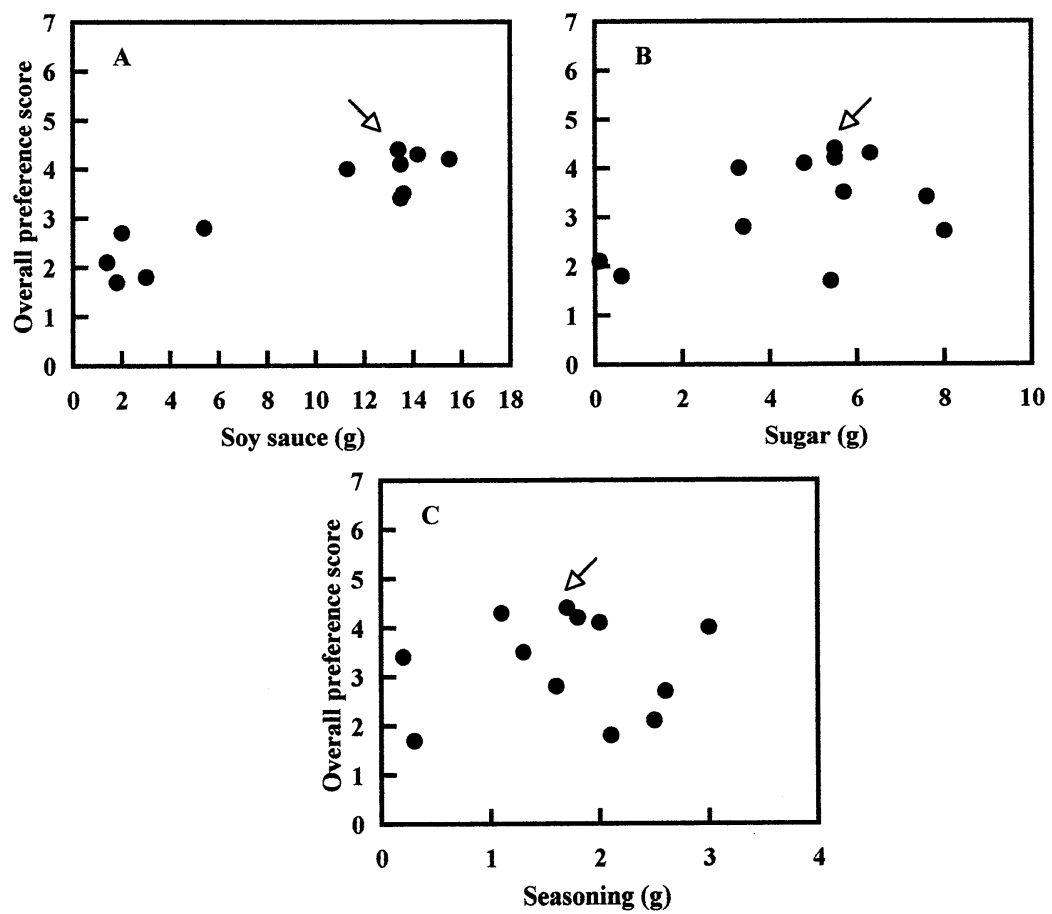

Fig. 3 Mapping results of the soy sauce weight, sugar weight and bonito broth seasoning powder weight in the solution generated by random centroid optimization.

A : Soy sauce weight, B : Sugar weight, C : seasoning powder weight

The arrow indicates the optimum points. 


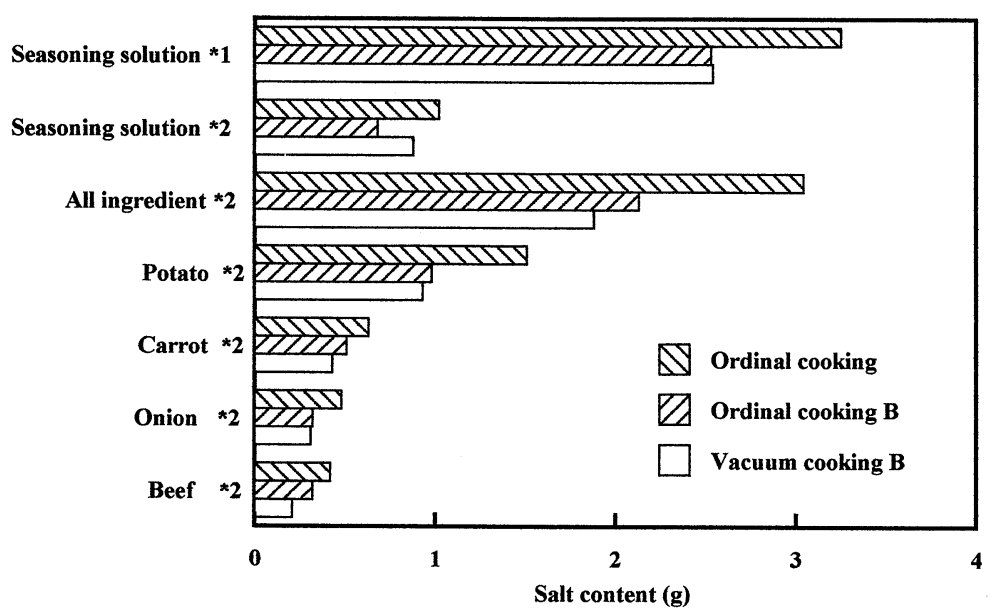

Fig. 4 Comparison of the salt content in the solution and ingredient cooked by ordinal cooking and low-salt vacuum cookinge.

The conditions for ordinal cooking were the avrage values of eight popular cooking books. Ordinal cooking B was cooked by the same concentration of vacuum cooking B.

*1 : before cooking $* 2$ : after cooking

下することはないと推察される.

これらの結果から, 真空調理は減塩食の調理法として も有効であることが RCO 法を用いて少ない実験回数で わかった。

\section{4. 要 約}

真空調理による肉じゃがの最適減塩調理条件をランダ ム・セントロイド法（RCO 法）を用いて最少実験回数 で決定することを試みた。

肉じゃがは，プラスチック袋に一定量の野菜（ジャガ イモ，タマネギ，ニンジン）と牛肉及び調味液を入れ， 真空包装し，スチームコンベクションオーブンを用いて $100{ }^{\circ} \mathrm{C}$ で加熱した。 まず，一般的配合の調味料を用いて 20，30，40分加熱し，官能検査（順位法）で最も好まれ る調理時間を調べた。その結果は40分であった.

次に, 加熱時間 40 分, 加熱温度 $100^{\circ} \mathrm{C}$, 風味調味料重 量を一定 $(1.2 \mathrm{~g})$ として酱油重量 $(0 \sim 19.5 \mathrm{~g})$ 及び砂 糖重量（0～ $8.4 \mathrm{~g} ）$ の 2 つを要因として RCO プログラ ムによって示された条件で調理を行い，官能検査の総合 評価が最も高くなる条件を求めた。この場合, 奨油重量 $16.6 \mathrm{~g}$, 砂糖重量 $4.2 \mathrm{~g}$ が最適条件で, 普通調理品（一般 的配合の調味料で約20分間鍋で煮たもの）と比べ約 $33 \%$ の減塩効果があった．また，官能検査の総合評価は，普 通調理品肉じゃがと比べほとんど差がなかった。

さらに, 酱油重量 $(0 \sim 16.6 \mathrm{~g})$, 砂糖重量 $(0 \sim 8.4 \mathrm{~g})$,
風味調味料重量 $(0 \sim 3.0 \mathrm{~g})$ の 3 つを要因として RCO プログラムで同様に調理条件を求めた. その結果, 奨油 重量 $13.4 \mathrm{~g}$, 砂糖重量 $5.5 \mathrm{~g}$, 風味調味料重量 $1.7 \mathrm{~g}$ が最適 条件であった．この時は普通調理品と比べ $38 \%$ の減塩効 果があった：この場合の官能検査の総合評価も普通調理 品肉じゃがと比べほとんど差がなかった.

これらの結果から，真空調理は，肉じゃがの食味を低 下させずに減塩効果を得られることが RCO 法を用いて 少ない実験回数でわかった.

\section{文献}

1) Nakai, S. , Koide, K. and Eugster, K. : J. Food Sci. , 49 : 1143-1148, 1170 (1984)

2) Nakai, S : J. Jpn. Soc. Biorheol. 4, 143-152 (1990)

3) Dou, J., Toma, S. and Nakai, S. : Random-centroid optimization for food formulation. Food Res. Int. 26, 27-37 (1993)

4）西村公雄, 後藤昌弘, 今津屋直子, 中井秀了: 日本調理科 学会誌, 30, 9-16（1997）

5) Nishimura, K. , Imazuya, N. and Nakai, S. : Food Sci. Technol. Int. Tokyo, 4, 18-24 (1998)

6）脇 雅代: 調理科学, 22, 190-202（1989）

7）工業技術会：おいしい食品開発技術, 研修社, 東京, 486507 (1991)

8) Ghazala, S. : Sous vide and cook-chill processing for the food industry, Aspen Publishers, Gaithersburg, p.25-56 (1998)

9）後藤昌弘, 橋本和弘, 山田喜八：日食科工誌，42，50-54 (1995) 
10）後藤昌弘, 彼末富貴, 西村公雄, 中井秀了：家政誌, 51 , 251-255 (2000)

11）医歯薬出版（編）: 高血圧 - 心臓病の食事療法, 医歯薬出 版, 東京, p.38 (1992)

12）玉川和子, 口羽章子, 松下ッイ子 : 臨床栄養学実習書（第 7 版), 医歯薬出版, 東京, p.38-42 (1996)

13）水野弥千子, 水野綾子 : さあ始めよう!! おいしい糖尿病 レッスン, 朝日出版, 東京, p.62-64 (1987)

14）有本葉子 : 基本扔かず百科 Best 235 品, 鎌倉書房, 東京, p.72-73 (1994)
15）為後喜光 : 為後喜光の抢料理はじめて, 家の光協会, 東 京, p.64-65 (1993)

16）久松有子: 組合せ自由 簡単おかずでおいしい献立, 群羊 社, 東京, p.24 (1991)

17）村上昭子：簡単・ヘルシー和風おかず，講談社，東京，p. 82 (1992)

18）阿川佐知子： non-no 抢料理基本大百科, 集英社, 東京, p. 118-119 (1992)

19）川端晶子編：新版身近な食べ物の調理学実験, 建帛社, 東 京, p.37 (1993) 